\title{
The Promotion of Youth Work through Policies in the Context of South Africa
}

\author{
G.P. Baloyi \\ College of Education, Department of ABET and Youth Development, University of South Africa \\ Email: baloygp@unisa
}

\section{Doi:10.5901/mjss.2014.v5n20p1063}

\section{Abstract}

There is substantial evidence to support the premise that the promotion of youth work through national youth policies can be an effective tool in developing the rural communities in South Africa. The paper was conducted to promote youth work in rural areas. The aim of the study was to determine methods and support mechanisms to promote youth work and reach out to the youth in rural areas. A qualitative research approach was adopted to explore some of the challenges faced by the youth structures in rural areas. A sample of participants was randomly selected to participate in this study. The paper proposes a number of methods to assist and promote youth work in order to develop the rural communities.

Keywords: youth, national youth policies, rural areas, technology, the Constitution

\section{Introduction and Background to the Study}

Several youth legislative policy frameworks such as the National Youth Commission (NYC) Act 19 of 1996, the National Youth Policy (NYP) 2000 and the National

Youth Development Policy Framework (NYDPF) 2002/2007 has been developed. These legislative processes outline in detail institutional arrangements for youth development, a relatively new concept and perspective on how delivery of services to young people should occur, with their involvement and meaningful participation. However, the fact remains that the developmental challenges facing the youth, especially those out of the mainstream of development cannot be eradicated by a single sector of government (NYC 2009 : 2). This is true in the context of South Africa. At the Unisa Youth Work Conference, where this paper was presented, the point was made that collaboration with various structures in youth development remains vital in the $21^{\text {st }}$ century.

The NYP 2009-2014 forms part of a global trend of governments formulating youth policies to respond to the changing conditions of young people in the 21st century. While this policy focuses on the particular needs and circumstances of South Africa's youth, it locates them within the African family and the global community. As countries worldwide engage in a process of continuous policy renewal, the NYC Policy 2009-2014 seeks both to contribute to this process and be informed by it (NYP 2009:4).

It is therefore clear that young people should be regarded as the beneficiaries and agents of change and not as passive recipients of government services (NYP 2009:6). The results of Census 2011 revealed that the average age in South Africa was 25 , which means that the population is youthful. The country's unemployment rate is $29,8 \%$, of which approximately three million are young people between the ages of 17 and 24, who could and should be involved in some form of post-school education but who are walking the streets jobless. This is a cause for concern, especially when one considers that our youth are our future.

This paper seeks to contribute to the professionalisation of youth development practice through partnership. There is the need for higher education institutions to professionalise youth work. Unisa has endeavoured to meet this need by introducing a Diploma in Youth Development. The challenge is that most people with this qualification are not involved in youth work. This needs to be revisited and as the country needs to look at ways of ensuring that diplomatscan put their knowledge and skills to good use.

The NYP 2009-2014 is an essential planning tool guiding the country in its approach to youth development. This policy document contains inherent commitments by government, young South Africans and society at large to interventions and services that would have to be rolled out to ensure effective and efficient mainstreaming of youth development in the socioeconomic mainstream.

The context and rationale for the policy are informed by the fact that, in South Africa, as in many African countries, a significant part of the population comprises people under the age of 35 . This provides ample opportunity for the youth to 
contribute towards the growth and development of the country.

In focusing on the needs of young South Africans, the policy highlights priority target groups that include young women, youth with disabilities, unemployed youth, school-aged out-of-school youth, youth in rural areas and youth at risk. The policy further supports the key interventions that will provide for the holistic development of youth. The four pillars upon which the policy proposes specific interventions are education, health and well-being, economic participation and social cohesion. The recommendations arising from each of these themes will be applied to programme and project design. It is hoped that this will encourage the inclusion and active participation of young people in decision-making processes, policy, programme and project implementation. It is acknowledged that for the successful implementation of the policy, social partnerships need to be strengthened. The best way to do so is to define the roles and responsibilities of the key role players clearly and to determine the basis for such partnerships. However, government will ensure the successful implementation of the policy through intergovernmental coordination. With this objective in mind, it is imperative that capacity in the youth sector be strengthened. It is hoped that recognition of youth work as a profession will strengthen capacity while promoting the provision of quality services.

Although the NYP 2000 was never adopted, it remained a guiding policy for the youth sector and also gave rise to the development of National Youth Development Framework. The concept of youth work is certainly not new. Research indicates that this practice dates as far back as the 19th century. It arose from an increase youth population as compared with other population groups and the complexity of the various challenges facing young people such as unemployment, poverty, street youth and so forth.

At the time, youth work was practised mostly in churches and local communities where programmes and projects were implemented to meet the needs of young people. This practice is still in evidence. Through this practice, young people acquire the cognitive, social and emotional skills and abilities required to navigate through life's journey (Bapela 2012). Bapela (2012) adds that by holding the conference we will be strengthening the capacity to deliver effective youth development services by recognising youth work as a profession. Capable youth workers are young people who, with the properly guidance, can become well-informed policy makers and provide youth-friendly and youth-responsive services (Bapela 2012).

\section{The Research Problem}

The youth around the globe continue to experience challenges that threaten development in both the private and public sectors. Such challenges include, but are not limited to, high unemployment, crime, substance abuse, obesity, suicide, HIV and AIDS. The demographic pattern shows that young people between the ages of 15 and 35 constitute more than $40 \%$ of the population in South Africa. Young people hold the key to society's future. It is therefore imperative to support the government's efforts to invest in the youth. The paper explores and supports government's commitment to facing the ever-increasing challenges of young people to have an effective service delivery service channel. The research shows that although the practice of youth work appears to be new, it has been around for many decades. During the conference, the researchers demonstrated that if technology is properly used, it could reach out to many young people..

\section{Significance of the Study}

The importance of a study is judged by its contribution to furthering research and promoting knowledge (Kwake 2007:18). This study could potentially benefit the government and various structures that have an interest in youth work in South Africa and are in the process of researching and formulating policies about ways in which ICTs can be adopted to improve teaching and learning in an ODL environment. Scholars who are not involved in such policy analyses may also find this study of interest, particularly because it uses several contemporary examples of ICT policy debates to illustrate the value of socially and organisationally informed research. The aim of this study is to benefit the country and the youth in South Africa. It is hoped that students, academics, researchers, institutions, the donor community and the government will all benefit from this study.. The study is a significant research reference because of its scope and breadth, and has increased the researcher's knowledge and developed his expertise in adult basic education and youth development at Unisa.

\section{Scope and Limitations of the Study}

The scope of a study includes the area, extent or latitude it can cover, while the limitations of a study are the restrictions imposed on the research (Mugenda \& Mugenda 1999:41). These restrictions may either be internal (i.e. relating to the 
person conducting the study) or external (i.e. imposed by the environment in which the study is being conducted). Restrictions can also arise from the type of study being conducted (Kwake 2007:20). The section below presents the focus, research environment, time factor and methodological frames of the study. Because of the huge number of youth categories, which are dispersed all over the country, the researcher limited the study to youth development students in the ABET Department. Although it would have been interesting to include all the youth of the world, this would have required more time, resources and expertise, which the researcher simply did not have.

\section{Research Methodology and Discussion of the Study}

According to distance education scholars, research without theory is a meaningless exercise. This section outlines the research design, theory and methodology used in this study and explains how the research sample was chosen and the method used to collect data. The analytical techniques employed in the study are also explained. This is a conceptual paper and discusses the trends in and challenges of youth work in general.

The two theorists who have had a significant influence on adult teaching and learning are Malcolm Knowles and Paulo Freire. The work of these early writers focused on theories and their importance in framing the study project. Holmberg also emphasises that theory helps us to understand the future practice of a discipline. Holmberg provided insight into the value of having theory in practice. The theories on distance education help researchers to determine how distance students learn, and thus improve the practice of distance education. Perraton's (1988) theory of distance education comprises elements from existing theories of communication and diffusion as well as philosophies of education.

Knowles attempted to develop a distinctive conceptual basis for adult education and learning by popularising the notion of andragogy, which became widely discussed and used. His work was a significant factor in reorienting adult education.

Adult education should recognise the experience of learner and use that experience as resource for teaching and learning. Adult learners need to be self-directed, motivated and willing to learn - they cannot be forced to learn. Learners should be motivated and equipped with the skills for lifelong learning. Learners should be engaged in informal learning activities where they share and learn by doing. Educators should recognise and respect their readiness to learn, and learners should practise and refine the things they learn. They need to know why they should learn particular skills.

Freire made many significant contributions to the fields of adult education. His evolving thinking was based on the learner-centred approach. He viewed teaching as a political process, as an act of knowing and as a creative act. According to him, everyone knows something and a learner is responsible for building up knowledge and resignifying what he or she learns. According to Freire, a person learns through his or her own transforming action in the world (transformational learning). The learner constructs his or her own categories of thought, organises his or her life and transforms the world. Adult educators should engage learners in problem solving and social tasks, that is, critical pedagogy. Freire emphasises creating products, small group collaboration projects, presentations, portfolios, equality of education and equal chances for the disadvantaged. Education should be learner centred and educators should never spoonfeed learners, that is, not deposit information in the minds of learners. Education should also operate through dialogue and lead to emancipation, empowerment and freedom.

Apart from adult education theory, the researcher also used engagement theory (ET) to explore the topic fully. This theory emerged from Kearsley and Shneiderman's (1999) experiences in teaching in electronic and distance education environments. The fundamental idea underlying ET is that students must be meaningfully engaged in learning activities through interaction with others and worthwhile tasks. While in principle, such engagement could occur without the use of technology, Kearsley and Shneiderman (1999) posit that technology can facilitate engagement between teachers and learners and between learners themselves in ways which would be difficult to achieve otherwise - ways that enable the learners and the teachers to perform better in their educational activities and projects. ET is thus intended to be a conceptual framework for technology-based learning and teaching. With its emphasis on meaning and sharing of information, ET is consistent with the constructivist approaches to teaching and learning. Because it emphasises collaboration between peers and a community of learners, it can be aligned with situated learning theories.

ET is similar to theories of adult learning because it focuses on experiential and self-directed learning. The theory is based upon the idea of creating successful collaborative teams that work on projects that are meaningful to someone outside the classroom. It is based on three principles: relate-create-donate. The relate principle means that students should verbalise their problems to facilitate solutions - ICT can help find solutions to these problems. Create implies that learning should use technology to find solutions to problems and also problems of others to provide assistance in educational contexts. The third principle of donate emphasises the value of making a useful contribution to society or 
education while learning (Kearsley \& Shneiderman, 1999). The learning process can use or not use technology. Social media can also be valuable tools for teachers to engage learners in educational discussions, if the participants play a positive role and follow set ICT usage guidelines and policies in order to improve their education and also contribute constructively to a particular educational activity or problem-solving exercise (Engagement 2011).

The NYP 2009-2014 is part of a global trend whereby governments formulate youth policies that respond to the changing conditions of young people in the $21^{\text {st }}$ century.

In South Africa, professionalisation of youth work has been a long journey. This is despite the prioritisation of the education and training of youth workers by the Commonwealth Youth Programme in its Plan of Action for Youth Empowerment as well as efforts on our part to introduce qualifications in youth work (Deputy Minister 2012).

\section{Recommendations on the Way Forward}

There are an emerging trends, gadgets and technologies that can be used globally for collaboration. Even though some technologies have limitations, the information on media such as Facebook, Whatsapp and Twitter can be searched and viewed by anyone who has signed up on them. One can share one's thoughts and expertise on these media. The youth can use these technologies to interact and discuss trends and challenges affecting them in the society.

These technologies are popular means of communication in contemporary society and teachers, students and the general public can benefit from their use. However, numerous recent studies have shown that education in general has been slow to adopt social media. Students who register at Unisa probably have cell phones and internet access.

According to research, the present range of the Web 2.0 service providers offers a self-evident strategic technology framework. Without too much effort, online teachers and learners can quickly assemble dynamic, networked personal learning environments simply by adopting the most popular tools in any particular domain. Lamb and Groom (2010) cite the following example of how Web 2.0 can be used: After opening a gmail account, a user can publish websites with Blogger, manage groups and mailing lists with Google Groups, videoconference with Google Talk, write collaborating with Google Docs, track topics, Google alerts, share videos, et cetera. Web.2.0 is used for teaching and learning activities, advertising in companies, academic context, open educational resources, et cetera. The youth can use these technologies to discuss topical issues in their daily lives.

The general trend is that the students use technology for learning, for example, communicating, exploring, sharing, engaging and connecting with people and content in meaningful ways that help them to learn. Students use the Web 2.0 world as a "recursive process where two or more people ... work together toward an interaction of common goals ... by sharing knowledge, learning, and building consensus."

Unisa has an excellent learning management system (LMS) in place known as myUnisa. It is an online tool that is available to all registered students who have access to the internet. It is an asynchronous learning management system where students. Asynchronous delivery has advantages and disadvantages which the researcher discussed in depth in the literature review. According to Pullen and Snow (2007:143), it is interactive and accessible at any time on web pages. However, students who do not have access to the internet are at a disadvantage. When using technology facilities like myUnisa, students can learn anytime, anywhere, and they have access to learning resources. The lecturers are able to interact with students at all times. There are also interactive responses between the students and the lecturers.

Adult education is crucial for social change globally. Adult education addresses socioeconomic problems by empowering people with skills.

Wiki technology helps students participate and collaborate in order to promote knowledge. Although educationists agree that technology is a tool and not learning itself, the researcher's brief experience creating a blog and a wiki taught him skills that he could only acquire by doing. One needs to bear this in mind when working with wikis and blogs. Nowadays, there are tools that can be used for large numbers of students to enable them create and acquire knowledge individually and in groups. Wikis and blogs can be used to interrogate common issues and create a common solution.

Wikis and blogs are developed by participants with similar interests and this gives them a sense of ownership. Teachers facilitate learning by setting goals and standards, and they can edit the final work to compile one publication. The youth can engage in these technologies to empower one another and improve on their practices in youth work.

Signing up for Edublogs is simple and easy. All it requires is a person's username, email and self-created password. Individuals can choose their own blog title and preferred language. They can also determine their blog type, that is, teacher, student or other self-descriptive type. In Edublogs, one can write and save the draft, edit, preview and publish it. One can even edit the content that has been published. Most of these technological tools are user friendly.

A wiki is a set of linked web pages that can be edited by multiple users (Wagner in Schroeder 2009:182). Wikis can be server or web based, but web-based wikis are becoming more popular. To incorporate wiki technology into their 
teaching, universities need to encourage a participatory approach in which students actively contribute and produce content. The goal of wiki assignments is often to promote student engagement by using technology tools and systems. This approach creates a social connection that may extend beyond the formal teaching and learning environment (Richardson in Hazari, North \& Moreland, 2009). Use of a wiki is often based on different pedagogical perspectives and theoretical frameworks than is customary, and learning is more student centred (Beldarrain in Hazari et al., 2009).

\section{References}

Hazari, S., North, A. \& Moreland, D. (2009). Investigating pedagogical value of wiki technology. Journal of Information Systems Education 20(2):187.

Kwake, A. 2007. The role of ICTs in harnessing information for women in rural development. PhD thesis, University of Zululand, Durban, South Africa.

Kearsley, G. \& Shneiderman, B. (1999). Engagement theory: a framework for Ttechnology-based teaching and learning. Available at: http://www.home.sprynet.com/ gkearsley/engage.htm [accessed on 12 February 2013].

Lomas, C., Burke, M. \& Page, C.L. (2008). Collaboration tools. Educause. ELI Paper 2.

Mugenda, O.L. \& Mugenda, A.G. (1999). Research methods: quantitative and qualitative approaches. Nairobi: African Centre for technology Studies (ACTS) Press.

Pullen, J.M. \& Snow, C. (2007). Integrating synchronous and asynchronous internet distributed education for maximum effectiveness. Education Information Technology 12:137 - 148

Republic of South Africa. National Youth Commission. 2000. National Youth Policy. Available at: http://www.polity.org.za/polity/govdocs /policy/intro.html [accessed on 9 February 2013].

Republic of South Africa. National Youth Commission. 2002. National Youth Development Policy Framework (NYDPF) 2002-2007. Pretoria: Presidency of South Africa.

Republic of South Africa. National Youth Commission. 2006. Integrated Youth

Development Strategy for South Africa (IYDS): final draft. Pretoria: NYC.

Schroeder, B. (2009). Within the wiki: best practices for educators. AACE Journal 17(3): 181-197. 